\title{
Wood Identification of Ancient Temple Structures in Ladakh, Located in the Western Himalayas
}

\author{
Mechtild Mertz \\ Centre de recherche sur les civilisations de l'Asie orientale CRCAO-CNRS \\ UMR 8155, Collège de France, 52 rue du Cardinal Lemoine, 75005 Paris, \\ France \\ Mechtild.mertz@free.fr
}

\begin{abstract}
Microscopic wood identifications were performed on five Buddhist temple structures, three vernacular houses, two stupas, and two holy trees located in Ladakh, a region in the Indian state of Jammu and Kashmir in the Western Himalayas. Leh is Ladakh's capital and is located along the Indus River, the backbone of Ladakh. The vernacular buildings, stupa, and holy trees are located in Leh. Ladakh is a high-altitude desert with extremely scarce vegetation. Natural vegetation occurs mostly along the watercourses. The temples are located in villages along the upper Indus river valley, or along confluent rivers. From the 110 wood samples, 4 wood species were identified: poplar, willow, juniper, and pine. Building type, local availability, specific physical and mechanical properties of the wood species, and religious considerations were apparently the leading criteria for timber selection.
\end{abstract}

\section{Keywords}

wood identification - Pinus wallichiana - Populus sp. - Salix sp. - Juniper sp. - Ladakh western Himalayas - buddhist temples - vernacular buildings

During a stay from 16 September to 6 October 2014 in the cold desert area of Ladakh (Western Himalayas, India), wood samples were collected from five Buddhist temple structures, three vernacular houses, two stupas, and two trees 


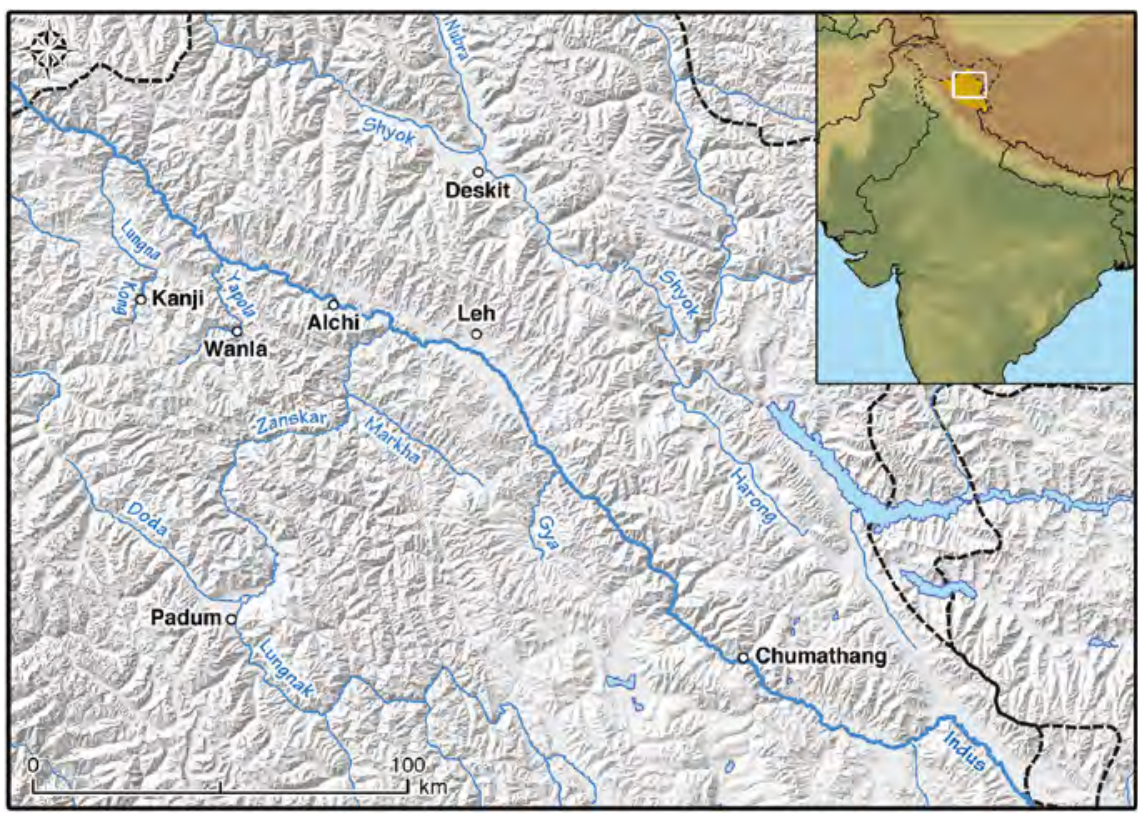

FIGURE 1 Map showing sampling sites: Leh, capital of Ladakh ( $3505 \mathrm{~m}$ asl); Kanji village (3850 $\mathrm{m}$ asl), Wanla village (3200 $\mathrm{m}$ asl); Alchi village (3060 $\mathrm{m}$ asl); Chumathang village (405० $\mathrm{m}$ asl).

MAP BY QUENTIN DEVERS, CRCAO

in cooperation with the Tibet Heritage Fund (THF). Samples were also collected from two archaeological sites in cooperation with Quentin Devers of the Centre de recherche sur les civilisations de l'Asie orientale (CRCAO). Sampling was carried out in buildings at five locations: Kanji village, Wanla village, Alchi village, the capital Leh, and Chumatang village. All building sites are situated along the Indus river valley or in the valleys of its confluent streams, the Yapola and Kong Tokpo (see map in Fig. 1). Identifying the wood species of the temple structures and secular houses in Ladakh will help, firstly, to prepare further restoration works to be undertaken with state-of-the-art techniques, and secondly, to understand the criteria of timber selection in ancient times. Most of the temples have already been restored, except for Chumatang temple, of which the restoration just started.

Therefore, the goal was to understand the criteria for timber selection in the Western Himalayas. Past research has shown that various criteria determine timber selection. The criteria depend mainly on availability, physical and mechanical properties, and cultural and religious aspects. This study is part of a greater project that comprises the study of the human-wood relationship in the whole Himalayan area. 
An initial study was undertaken in 2012-2013 in Sikkim, located in the Eastern Himalayas (Mertz et al. 2014). Since the climate and vegetation differ significantly between the Eastern and Western Himalayas, it is interesting to compare the timber tree species used for buildings in both areas.

\section{Investigation Sites of Secular Buildings and Temples}

The wood identifications were carried out in cooperation with the THF, a non-governmental organization registered in Berlin, Germany, committed to the preservation and restoration of historical buildings in the Tibetan realm. Since 1996, the THF has initiated the restoration of historic sites in Lhasa and the Tibetan cultural sphere extending over China, Mongolia, and India by funding and organizing the rehabilitation of numerous sites in collaboration with local communities. Since 2003, the THF has worked in Ladakh, mainly on the Leh Old Town Conservation Project (Fig. 2).

A total of 110 samples were taken from several of the traditional secular buildings in Leh previously restored by the THF, from one temple of which restoration just started, and from temples that had formerly been restored by the Indian-Swiss Achi Association.

The collected wood samples were prepared and identified at the Research Institute for Sustainable Humanosphere (RISH) at Kyoto University. The

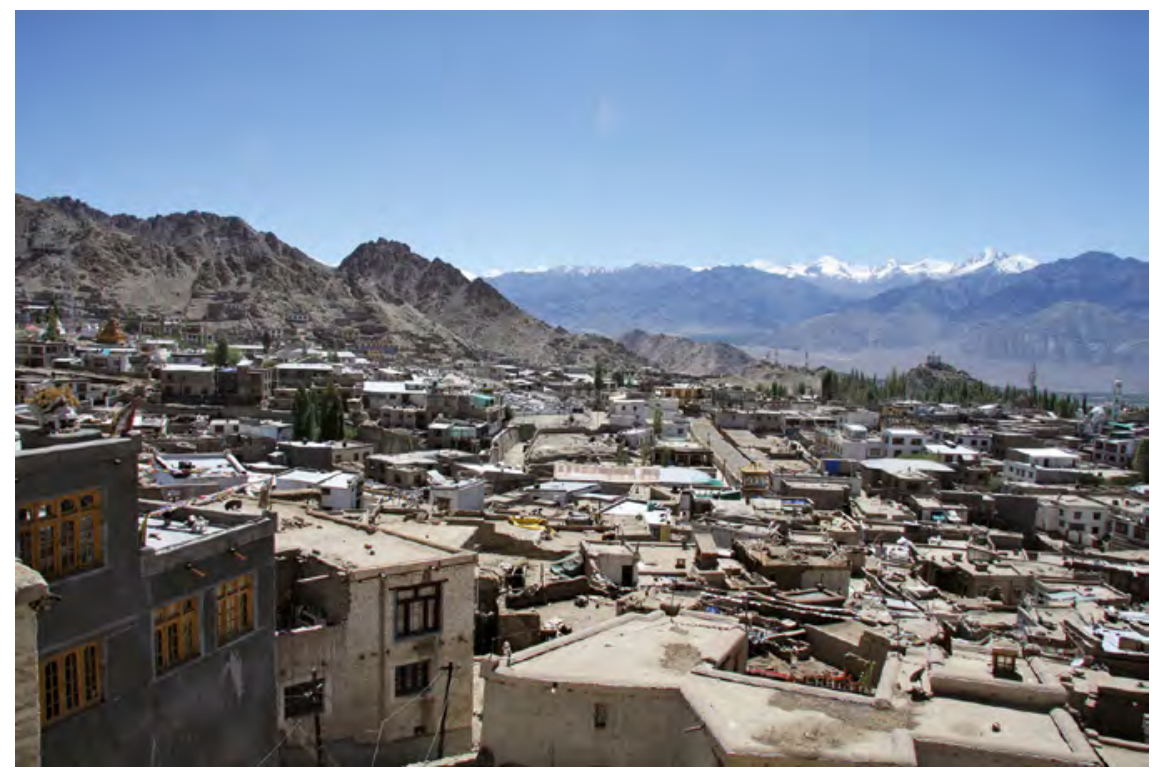

FIGURE 2 Old Town of Leh, capital of Ladakh (3505 $\mathrm{m}$ asl). 
samples were soaked in water for two days for softening. For the preparation of the microscopic slides, thin hand sections were taken in transverse, radial, and tangential directions $\left(15^{-25} \mu \mathrm{m}\right.$ thick) by means of a double-edged razor blade. Gum-chloral was used as a slide-mounting medium. The slides were studied under an optical microscope (Olympus model Bx51, Japan) with a magnification of 40-400 $\times$ and photos were taken with a digital camera, (Olympus model D P73, Japan) (see also Mertz et al. 2014). The results are listed in the Appendix at the end of the paper. The various traditional buildings and temples are described below, along with an idea of how people live in and cherish traditional buildings.

\subsection{Roke Bano House (Figs 3 and 4) - Early 1900 s}

This house, restored by the THF, belongs to the Bano family, a Muslim family. They moved to a larger house in a village near Choglamsar, a Tibetan settlement $7 \mathrm{~km}$ from Leh. The family, including five children and a 75 -year-old mother, still cherish their old family house. They appreciate the old beams that are common in all of the traditional houses. This kind of social connection and cooperation is hardly felt in newly constructed houses. Over the last five years, more and more concrete houses have appeared in Leh Old Town. The mother, Roquia Bano, after whom the house was named, said that "In the past, Muslims

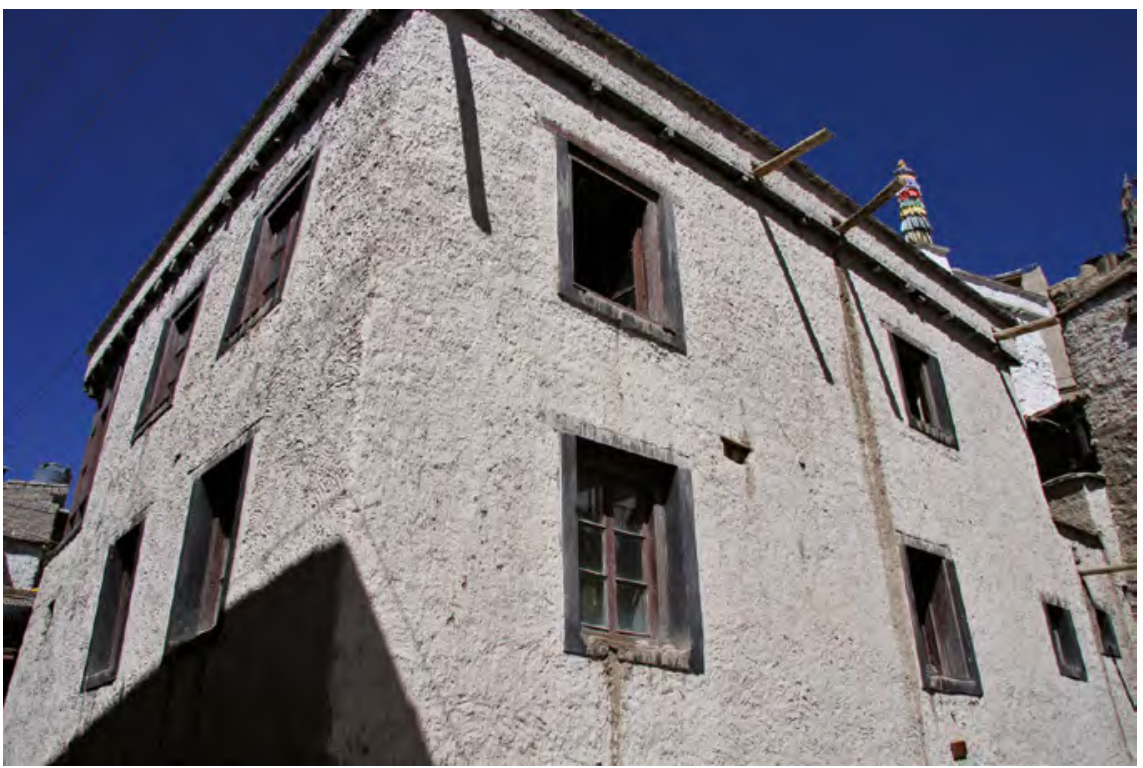

FIGURE 3 Roke Bano House dating from the early nineteenth century. The house belongs to a Muslim family but is rented to the THF staff. 


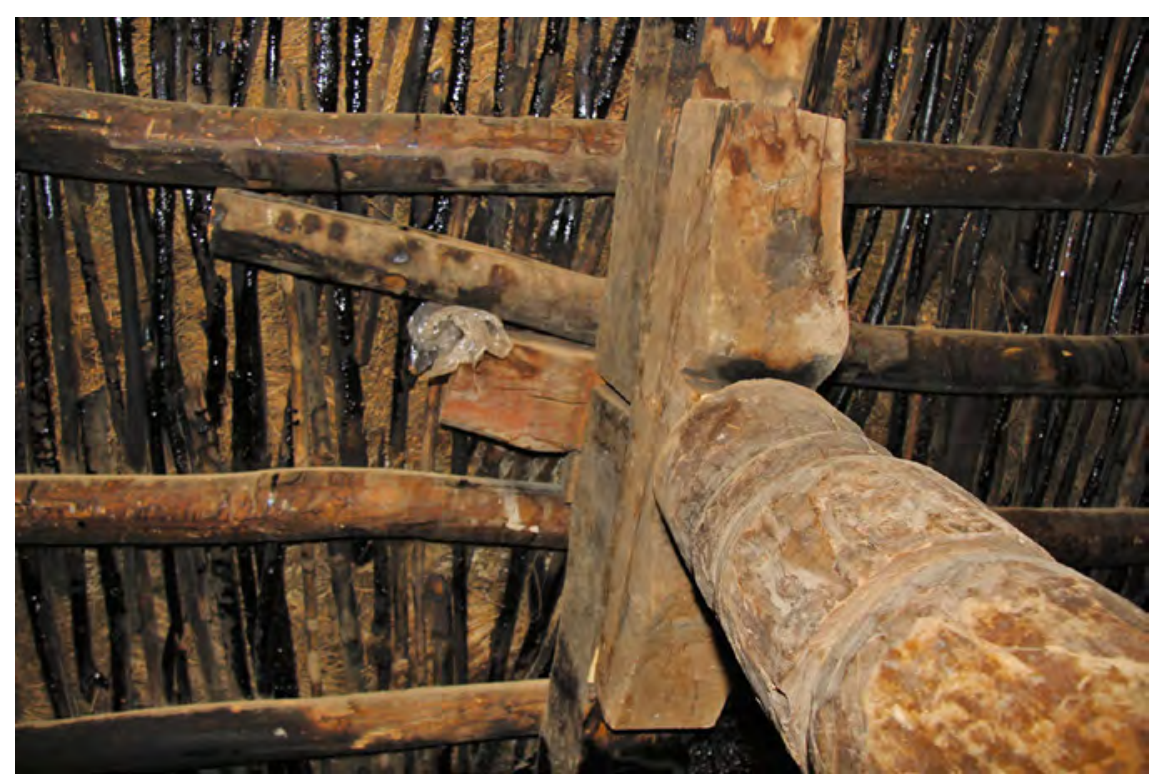

FIGURE 4 Main pillar (poplar wood) and a bracket made of willow. The purlin is made of poplar. The rafters and ceiling-covering sticks (called "talu") are made of willow. The sticks are cut from poles of pollarded willows. Continuous lopping of the top of a tree encourages fresh growth into new shoots producing poles (Corkhill 1979).

and Buddhists had good relationships in the Old Town, living together in peace and harmony."

The Roke Bano House itself shares a common wall with the White Maitreya temple. On the ground floor, the family used to store wood and cattle dung in the winter; in the old days, they kept camels. At present, the THF rents the flat roof floor for its staff members (Chan 2010).

\subsection{Sofi House - Early 19oos (Fig. 5)}

The Sofi House is located next to the Stagopilog Stupa Gate.

The wooden doors and benches at the main entrance porch, as well as the hanging wooden balconies, are signatures of Kashmir-style houses. It is home to four families, all related. The house is warm in winter and cool in summer. The Sofi family, originally from Srinagar in Kashmir, came to trade in Ladakh (Chan 2010). 


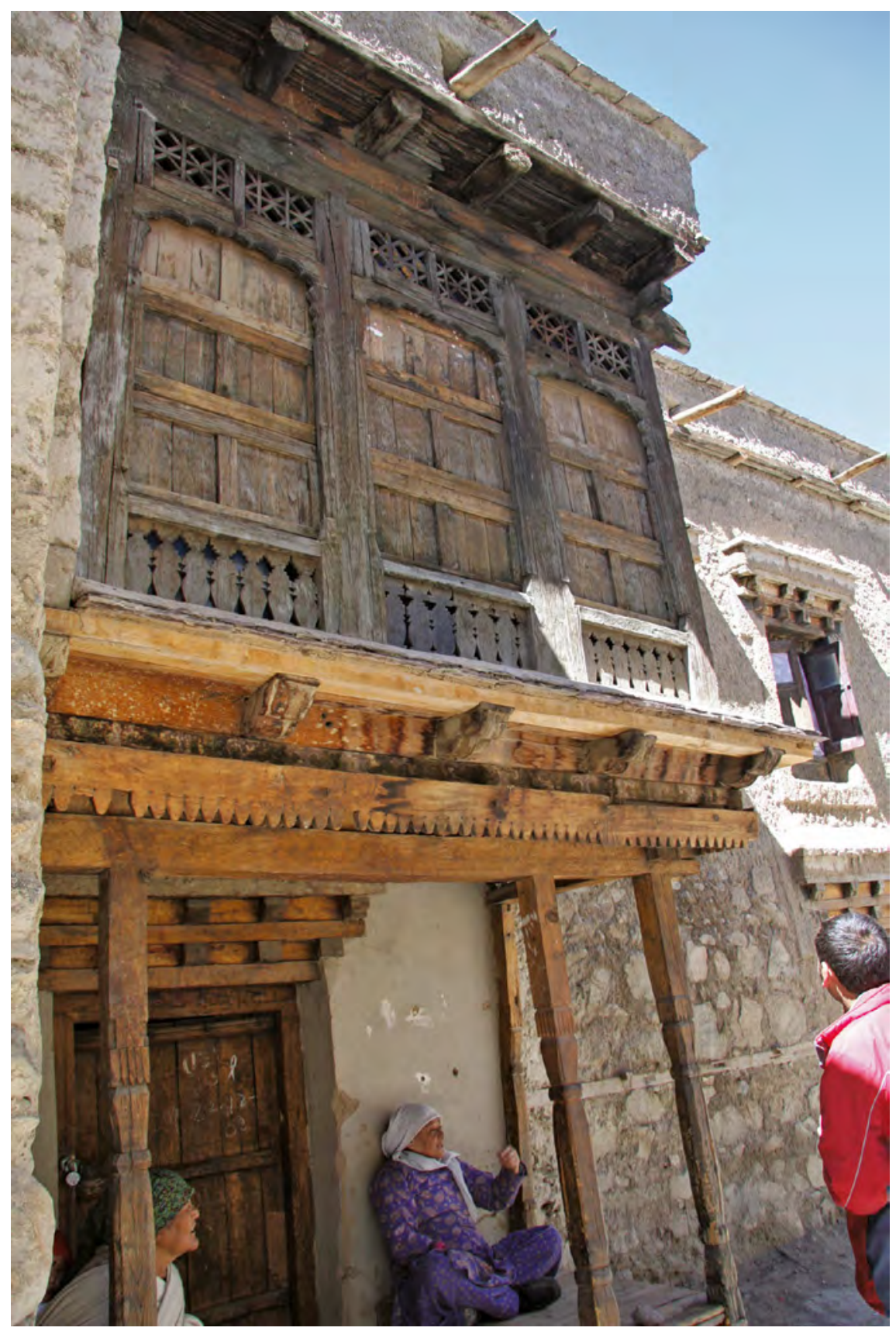

FIGURE 5 The Sofi House, dating from the early nineteenth century, shows the beautifully carved wooden doors and balconies typical of a Kashmir-style house. The rafters, beams, and pillars are made of poplar. 


\subsection{Stagopilog Stupa Gate (Fig. 6)}

This is a small gate in the form of a stupa, or chorten in Tibetan, above a small street next to the Sofi House. A stupa, or chorten, is a mound-like hemispherical structure containing relics, typically the remains of Buddhist monks and nuns, that is used as a place of meditation.

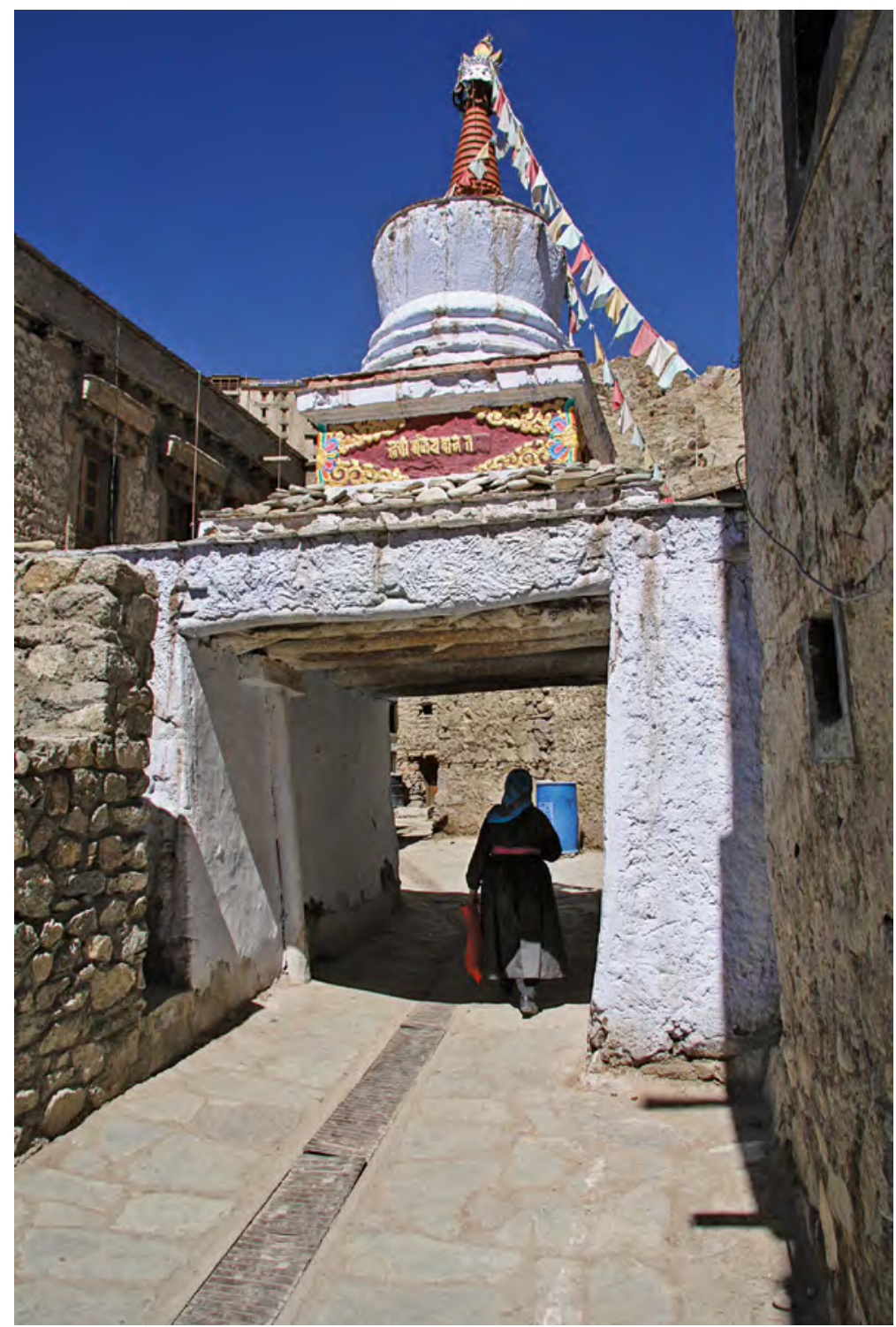

FIGURE 6 Stagopilag Stupa Gate, located next to the Sofi House (left). One beam of the ceiling is made of willow. 


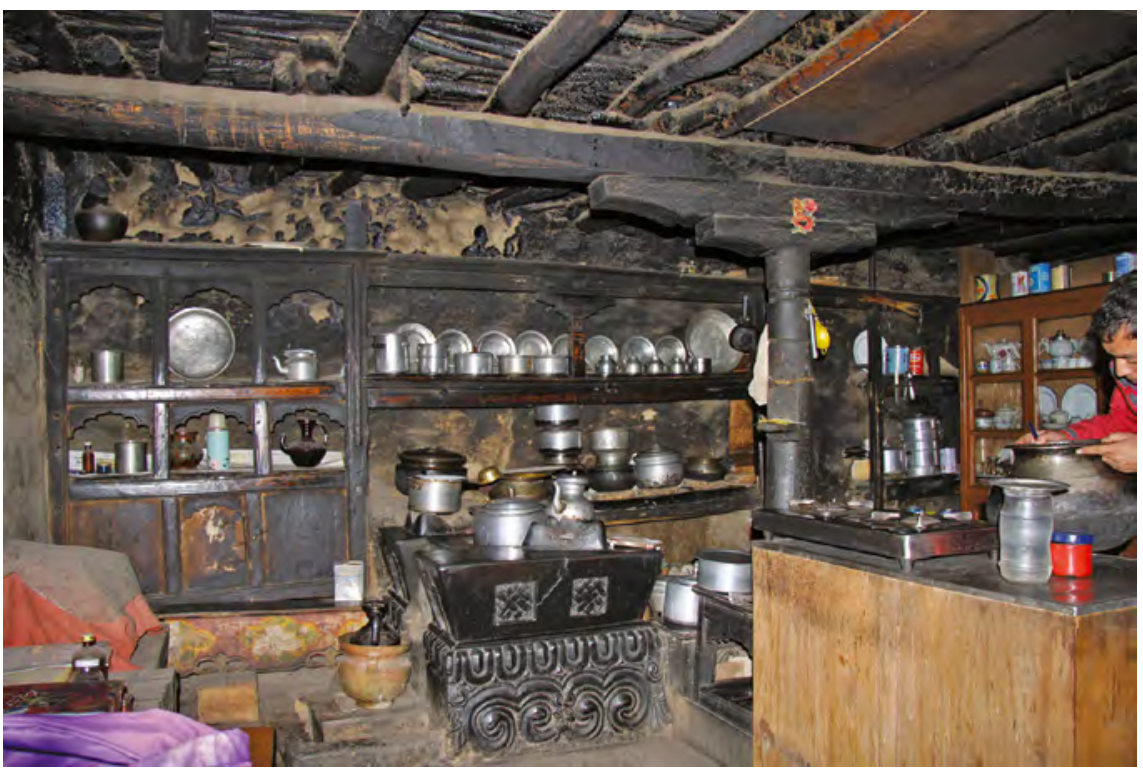

FIGURE 7 Interior of the Lakruk House dating from the early 170os. It belongs to a Buddhist family. The whole inner structure appears to be made from poplar, with the exception of the ceiling sticks ("talu") made from willow.

\subsection{Lakruk House - Early 170os (Fig. 7)}

This house belongs to a Buddhist family. A 70-year-old Ladakhi nun, Ani-le Thupstan Choedon, lives alone in the family's Lakruk house, which overlooks the old town. The house was named after one of the great-grandfathers of the family. A prominent Buddhist family, they have hosted many rimpoches (spiritual leaders).

The Leh Old Town Initiative and THF are renting the top floor of the Lakruk House for their office and residential use. During the day, Ani-le sometimes climbs the narrow stairs up to the terrace, where she can be with the staff and volunteers (Chan 2010).

\subsection{West Stupa Gate (Fig. 8)}

This is a small gate above a small pathway next to the Central Asian Museum.

\subsection{Two Holy Trees (Sikh Trees) Next to the Central Asian Museum (Fig. 9)}

These two impressive trees are landmarks of Leh Old Town. Many myths are told about them. One signboard says the following about the dead tree: 


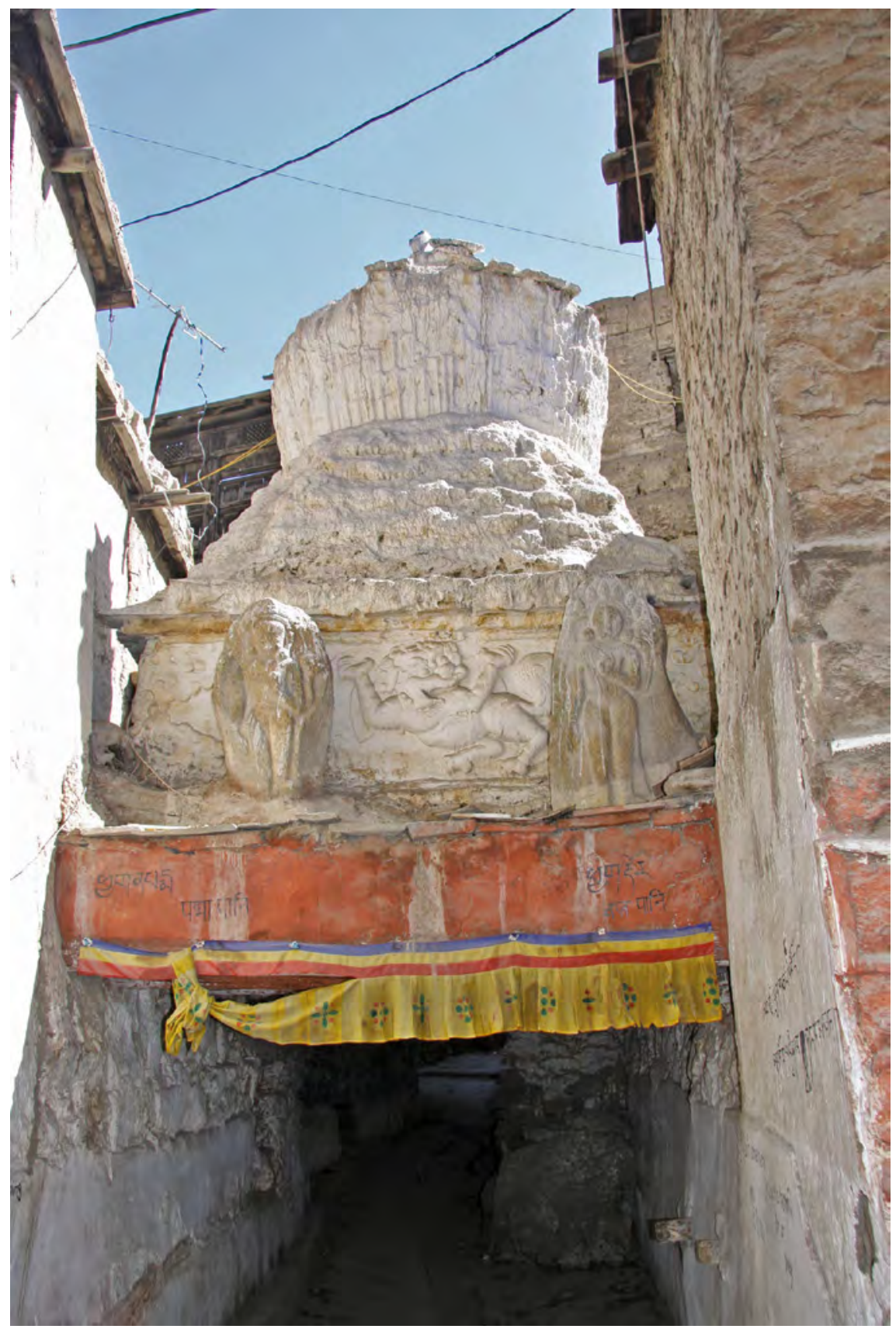

FIGURE 8 West Stupa Gate squeezed between two houses. 


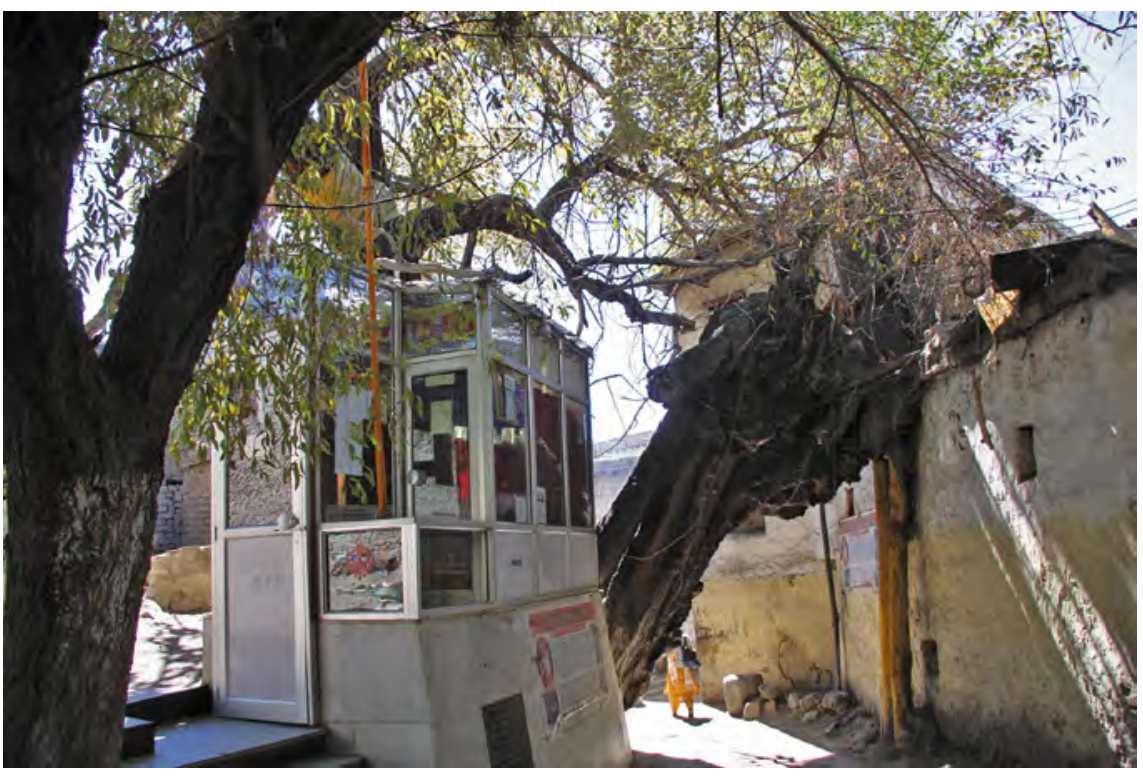

FIGURE 9 These two holy trees are impressive landmarks of Leh Old Town. The one on the right is dead and the one on the left is living; both are poplar trees.

The 'Sacred Tree' is revered by the local people of the Ladakh region, as the great prophet Rimpoche Lama visited this place in the year 1517 . Master, or Guru, Ji put down his walking stick at this place. With the passage of time, a huge tree grew from the stick in the desert area of Ladakh, where there were no trees at that time. For five hundred years, this sacred tree has been well known among all the people, including our Buddhist and Muslim brethren, both for its sacredness and Guru Ji's most memorable journey to spread the message of truth, peace and love there.

\subsection{1 $\quad$ Living Tree}

"The real aim of Guru Ji was to establish greenery in an arid climate, and this tree also is there to remind us to take care of the environment."

\subsection{Kanji Village: Tsuglag-khang Temple-3850 m (Fig. 10)}

The Tsuglag-khang Temple is approximately 700 years old and roughly contemporary with the temple of Wanla village (next entry). It dates from a period when Kanji was part of a local kingdom ruled from Wanla.

The temple is a one-room structure built of river stones, earth, and wooden beams. The interior is decorated with three larger-than-life-sized clay sculptures. In the middle is the four-armed Shadakshari Lokeshvara, a popular form of the Bodhisattva Avalokiteshvara, flanked by the Medicine Buddha 


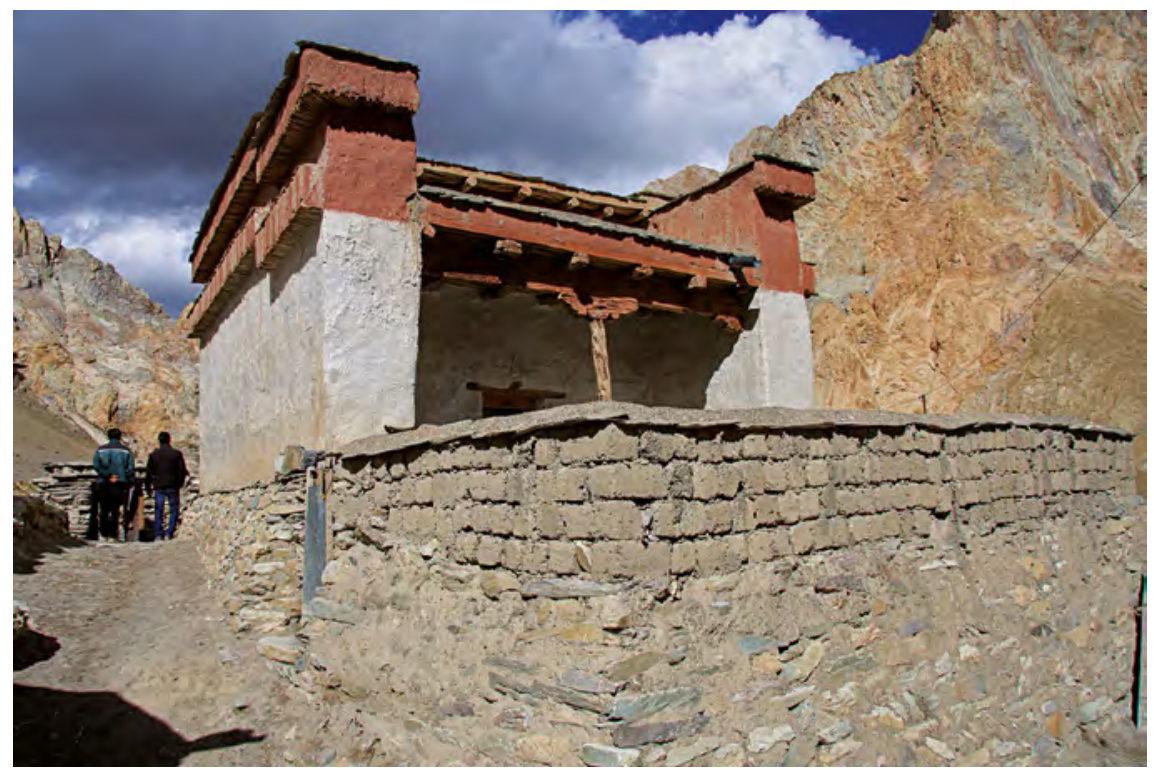

FIGURE 10 The Tsuglag-khang Temple dating from 1300 is located in Kanji Village on the Kong Tokpo River, a confluent of the Indus River. It is made of juniper.

(Bhaisajyaguru) and the green form of the goddess Tara. Its walls are covered with paintings, including six mandalas. Although the exact identification of these is not yet possible, the mandalas on the left-side wall are dedicated to the main Bodhisattva Vajrasattva and the Buddha of long life Amitayus, and those on the right-side wall to the Buddha Shakyamuni and Vairochana. On the entrance wall, the left mandala is damaged to the extent that it must be considered unidentifiable. The one to the right is dedicated to the fierce deity Vajrapani. Due to the quality of the interior decoration and its fragile state of preservation, this temple was selected by the Achi Association in 1999 as its first monument conservation project. The conservation problems mainly resulted from an overload of the roof structure accumulated over centuries of casual repairs. The heavy load caused instability and cracks in the walls and resulted in an outward drift and partial detachment of the east wall; in consequence, water penetration through the roof soiled and partly destroyed the precious paintings.

\subsubsection{Conservation and Restoration Measures}

After more detailed survey work on the building structure and the interior paintings in 2000, the stabilization and restoration of the temple structure were executed in the following years. The underpinning of the foundation and reconstruction of the damaged roof and tie beams was stabilizing the building 
and preventing further damage to the interior decoration. Parallel to this, the Achi Association carried out conservation of the paintings, consisting of their cleaning and stabilization and the filling of cracks. The work was completed in 2008. Currently, the sculptures are undergoing conservation work and the missing areas of the paintings are being reconstructed.

The final aim is to do equal justice to both, the religious utilization of the temple, and to the art-historical importance of the paintings and sculptures. Their cautiousness in the painting and reconstruction arose from the desire to restore the former unity of the interior decoration, and to render its religious meaning clear. All of the repainted and reconstructed sections are easily distinguishable from the originals, when closely observed.

The practical conservation efforts on the temple go together with the commitment to assisting the village community in maintenance strategies and capacity building in preventive conservation. In cooperation with the Achi Association, the University of Udine (Italy) is preparing a conservation manual on the historic Kanji village (ACH I Association).

\subsection{Wanla Village: Chuchig-zhal Temple - 3200 m asl (Fig. 11)}

The temple of the Eleven-headed Avalokiteshvara (Chuchig-zhal) was built about 700 years ago within the hilltop fortress of a local ruler, Bhag-dar-skyab.

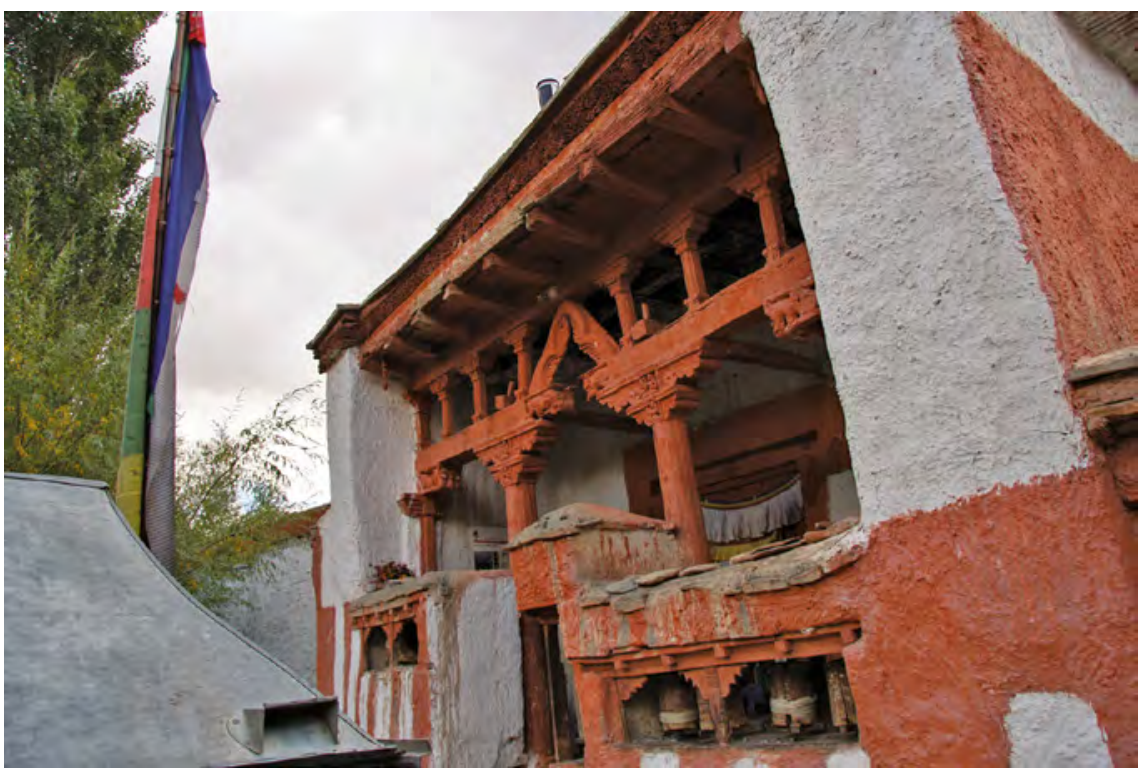

FIGURE 11 The Chuchig-zhal Temple of Wanla Village dates from ca. 13oo, and is located on the Yapola River, a confluent of the Indus River. The pillars are made of Pinus wallichiana and the beams of willow. 
It is said to be a copy of the Sumtsek ("three-storied building") at Alchi, the only other temple of this type in Ladakh. Commonly referred to by the name of the main deity in its southwestern niche, in the inscription on its southeastern wall it is called Tashi Sumtsek ("The Auspicious Three-storied"). The temple was built on a mandala plan, with an eastern entrance porch and three niches containing colossal standing statues of Maitreya, Avalokiteshvara, and Shakyamuni. The central space rises through two stories into the rooftop lantern. The internal walls on all levels are completely covered with wall-paintings. Carved and painted wooden pillars, capitals, and beams complete the décor of the porch and interior.

\subsubsection{The Need to Intervene}

Structural investigations of the temple revealed that the roof system had a thickness of up to $110 \mathrm{~cm}$ and that the layer-wise increase of the roof structure was the result of maintenance work over the centuries. These excessive roof loads affected the stability of the temple and caused cracks and detachment of the decorated wall plaster in the interior. According to witnesses, some of these cracks developed only over the last 20 years. The main beam at the gallery level is broken on one side, and is propped up from below by a temporary post. Further damage to the plaster and paintings was caused by a defective rainwater spout, which led to water penetrating the wall. All of the paintings were covered with the greasy lampblack of the countless butter-lamps that were burned in the temple during the centuries. The paintings on the ground floor became nearly invisible.

\subsubsection{Conservation Measures}

Temporary supports were erected in the left-hand-side apse in 1999, followed by an investigation of the wall foundations down to the rock base, and consolidation of the masonry below ground level. Before the works on the roof structure started, the detached and finely painted plaster on the wall above the broken main beam had to be secured in those places that were in immediate danger. In 2006, measures to diminish the roof load were begun, and in 2008 the structural reinforcement was carried out. Since 2003, working hand in hand with the architects, the conservators have investigated, consolidated, and cleaned the interior wall paintings.

\subsubsection{Renovation of the Roof}

Over the centuries, several attempts were made to seal the roof against water with the aid of new, additional layers of loam. This led to massive overloading of the structure that is evidenced by the wide cracks in the masonry. 
In 2005, the thickness of the roof at the front was reduced by $43 \mathrm{~cm}$ and at the same time a drain was installed on two sides.

The relief offered by the works performed since 2005 led to a relief of more than 28 tons on an area of $32 \mathrm{~m}^{2}$. The latest roof layer, with a thickness of 10-18 $\mathrm{cm}$, was installed in two layers, using an improved, traditional technique: markalak, loam soil, fluvial sand, horse dung, and straw. In the particularly critical zone of the transition to the top ceiling (parapet zone), a fiberglassreinforced strip of plastic was installed to protect the painted areas by preventing "rivulets" on the inside. In 2008, the roof surface above the main recess was refurbished. The existing roof of $1 \mathrm{~m}$ thickness was removed, and a new lightweight aluminum construction was installed. These beams are supporting the new external roof independent from the inner roof. The original inner ceiling was suspended from spring-born bars (ACHI Association).

\subsection{Alchi Village: Alchi Monastery - 306o $\mathrm{m}$ asl \\ 2.9.1 Lotsawa Lhakhang - 11-12th Century}

On the central wall of the temple, there is a presentation of Shakyamuni, surrounded by the translator Rinchen Sangpo at his left and the four-armed bodhisattva Avalokiteshvara on his right. On the left wall, next to the Buddha Amitabha, there is a mandala of Avalokiteshvara on his left and a mandala of Amitayus on his right. A painting of Mahakala is situated above the entrance door. On the right wall, one can find in the center a representation of Akshobhya; on its right, there is a mandala of himself, and on its left, a heavily deteriorated mandala (Gnoud et al. 2011).

The temple's timber structure is made of poplar, except for one carved Lion-bracket that is made from a conifer, probably juniper.

2.9.2 Tsa Tsa Puri (Three Separate Rooms, One Two-Storied, the Others One-Storied) - ca. 15th Century (Fig. 12)

On the hill dominating Alchi are two temples that are guarded by the monks of Rizong. These temples called Tsa Tsa Puri, were named by the Lunpo of Alchi by the name of Tugdje Chenpo, "the great compassionate," which means Avalokiteshvara. The paintings that decorate these buildings are of a very particular style: the only style they can be compared with are those of the principal cave of Saspol. It is supposed that they date from the fifteenth century.

\subsection{Chumathang Village: "Old Temple" - 4050 m asl (Figs 13 and 14)}

Chumathang is a village located about $138 \mathrm{~km}$ southeast of Leh. It lies on the banks of the upper Indus river. The restoration of the "Old Temple" started 


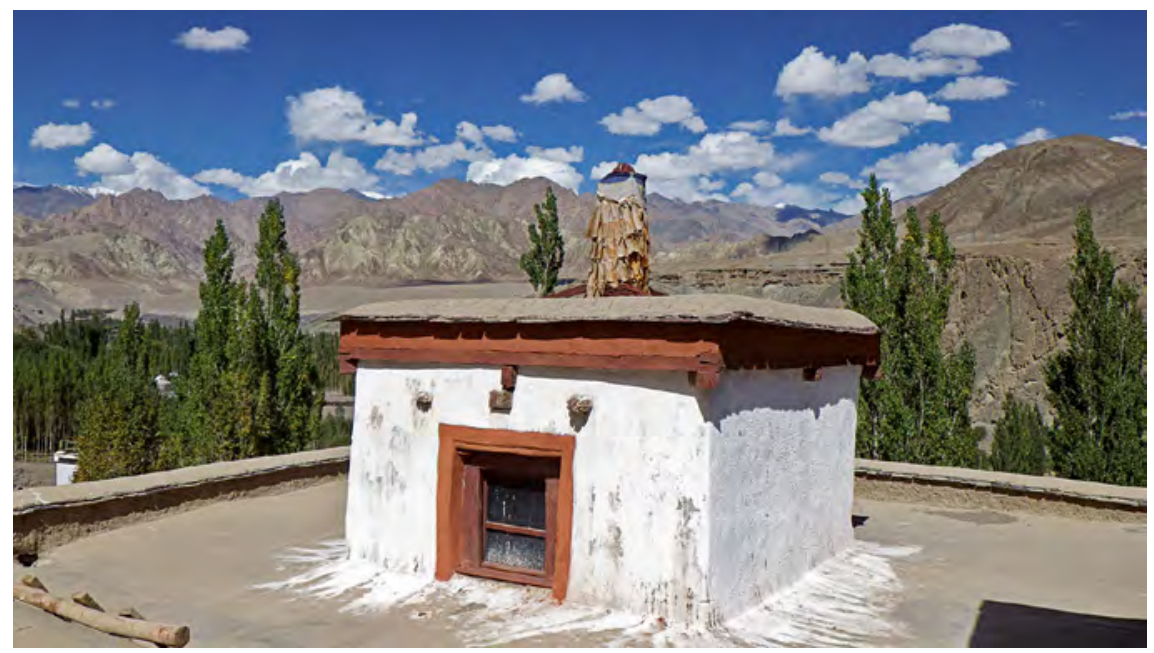

FIGURE 12 The Tsa Tsa Puri temple, located in Alchi next to the Indus River, probably dates from the fifteenth century. The temple is mostly made from poplar, while the floorboards are made of juniper.

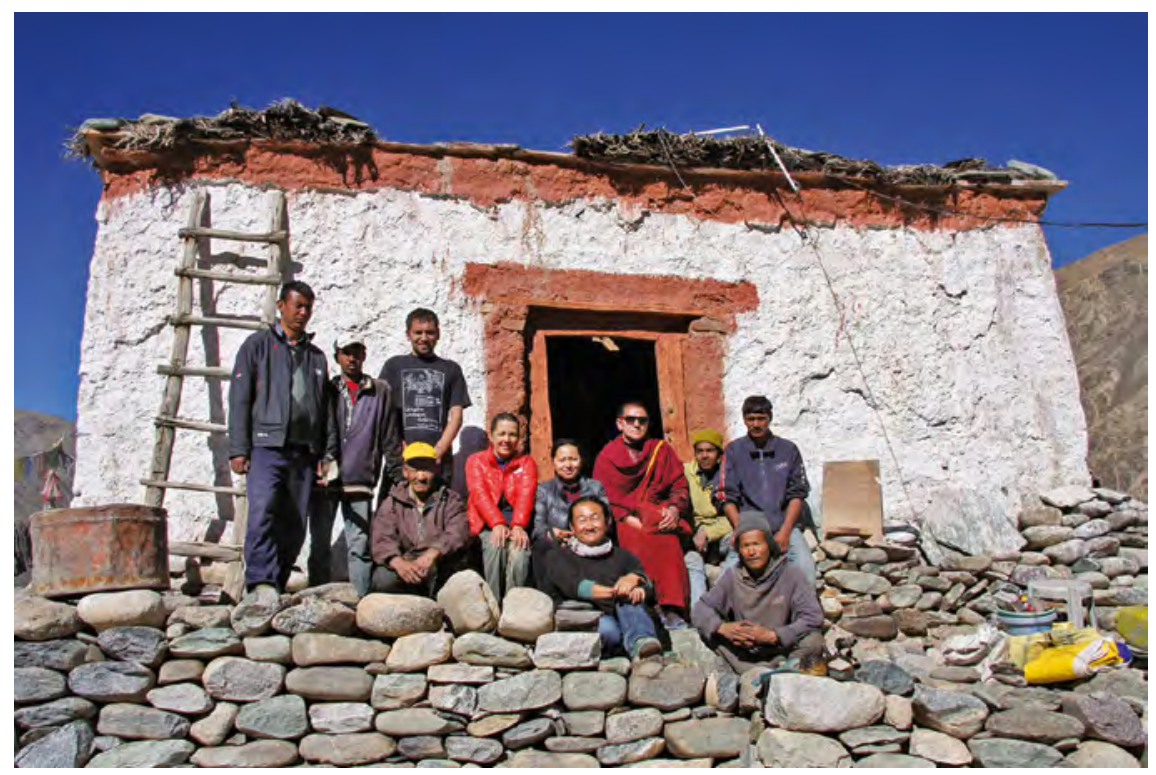

FIGURE 13 The Tibet Heritage Fund team together with the carpenters and masons before starting the restoration of the "Old Temple" of Chumathang village, located on the upper Indus River (4 October 2014). 


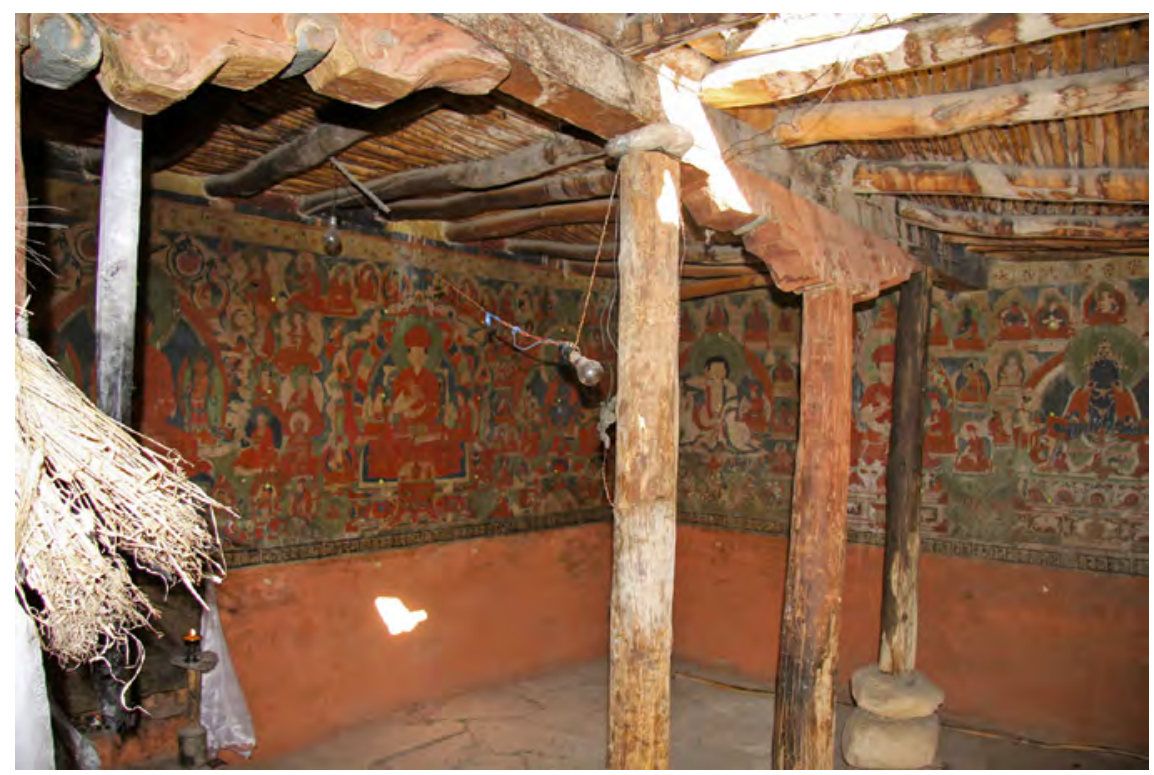

FIGURE 14 Interior of the "Old Temple" showing the wooden structure and the wall paintings slated for restoration. The wood identifications revealed that most of the structural timber is poplar, while some rafters are made from willow.

with our arrival. First, the responsible priest performed a purification ritual. Then, the THF team started consolidating the wall paintings while the artisans, carpenters, and masons prepared wooden boards for new doors, and soil for plastering. During these activities, the wood sampling was performed.

\section{3}

\section{Results}

From 111 collected samples, 4 wood species were identified:

Populus sp. (poplar)

Salix sp. (willow)

Juniperus sp. (juniper)

Pinus subgen. Haploxylon (five-needle pine/soft pine)

The vernacular buildings in Leh (3505 $\mathrm{m}$ asl) are mainly made of poplar (Populus sp). This is the timber mostly used in the traditional buildings in Leh; in the temple buildings in Chumathang village, located in the upper Indus river valley (4050 $\mathrm{m}$ asl); and in Alchi village, located on the lower Indus river (3060 $\mathrm{m}$ asl). However, in room 2 of the Alchi Monastery, the flooring is made 
of Juniperus sp. Juniper is more durable than poplar and was therefore used for the flooring panels, which are prone to abrasions.

We were very suspenseful about the results on the two sacred trees: The old dead tree that was said to have grown from a walking stick, brought from far away by the holy Rimpoche Lama, a great prophet, in the year 1517, was a poplar.

The living tree was planted after a wish by this holy man to plant "greenery" for a "clean green environment." This tree was also a poplar tree.

The most probable candidate for the poplar wood is Populus euphratica, also called the Indian poplar. The late Gamble of the Indian Forest Department, Dehradun, mentioned the so-called Bahan poplar distributed in the Upper Valley of the Indus: "this being, possibly, the original home" (Gamble 1972, p. 691).

The wood of Salix sp. was used for specific purposes, such as the ceilingcovering sticks called "taru," in all of the investigated buildings. In some cases, willow was used instead of poplar, like in the Roke Bano House in Leh, in the Stupa Gates in Leh, and for the front porch of the temple in Wanla village, recently restored by the Swiss ACHI Association.

The temple in Kanji village ( $3,85 \circ \mathrm{m})$, located along the Kong Tokpo river (a confluent stream of the Indus river), is made of Juniperus sp. As this wood is very hard, it was also used for the flooring boards in room 2 of the Tsa Tsa Puri of Alchi Monastery, while the rest of the temple is made of Populus sp.

Finally, a piece of juniper, an incense wood used by locals in Leh, was also identified, so we could confirm its local use as incense for purifying living spaces.

The main wood of the Chuchig-zhal temple of Wanla village $(3,200 \mathrm{~m})$ is a Pinus species with smooth ray tracheids. Its cell walls are thin, with no ornamentations. It belongs to the group of "soft pines", scientifically belonging to the subgenus Haploxylon. As Pearson and Brown (1932) explain, of the five pine species indigenous to India, only one belongs to the subgenus Haploxylon, which is a five-needle pine, while all others belong to the subgenus Diploxylon, which are two-needle pines, with thick dentate-shaped ray tracheids. Therefore, it is possible to assume that the timber of that temple is made of Pinus wallichiana (syn. Pinus excelsa). Five-needle pines usually grow straighter than two-needle pines and are easier to work with.

As for the samples of the archaeologist Quentin Devers, sample no. 1 from a lintel of the entrance gate of Shey City was Populus sp. and sample no. 2 was a liana or vine. 


\section{Conclusions}

The wood identifications of the temple structures showed a restricted number of wood species, compared with the temples identified in Sikkim of the Eastern Himalayas. This becomes understandable, when comparing altitude and climate. The temples in Sikkim are located at an altitude of 1400-2800 $\mathrm{m}$, whereas those of Ladakh range between $3000-4000 \mathrm{~m}$. More important is the climate, with an annual rainfall of 2700-3200 mm in Sikkim, with a heavy monsoon between June and September, whereas Ladakh, which is a cold desert area, has only $102 \mathrm{~mm}$ of annual rainfall (Leh) (Wikipedia). The forests of Sikkim are much more species-rich than those of the Ladakh region.

As for the criteria of wood selection, the choice was limited to the four timber tree species poplar, willow, five-needle pine, and juniper.

Another criterion, that of the sacredness of a tree, could be mentioned here. The Tsuglag-khang Temple of Kanji Village was made from juniper. This timber is considered a purifying wood, as it is used as incense for purification.

As a final remark, it is important to note that a great number of the samples showed that the wood was deteriorated. The deteriorated or desiccated poplar showed crystal-like inclusions under the microscope (Fig. 15). It is highly possible that the extremely desiccated wood led to the replacement of the wood structure by silica, or by calcium carbonate (Cartwright 2015). The more advanced the desiccation, the greater the number of crystals. Wood identification was possible because of the quantity of material available and because comparisons with other samples were possible.

\section{Acknowledgements}

The author wishes to thank the THF, especially Yutaka Hirako, for helping with the travel organization and with the wood sampling. I am also grateful to Jigmet Namgial of Achi Association India (Leh Office), who introduced me to the Alchi Monastery and its temples. I am indebted to my institution, the CRCAO, for their travel support, and its members Quentin Devers, who draw the map of Ladakh, and Laurianne Bruneau for a fruitful cooperation. I also want to thank the World Wood Day Foundation and the International Wood Culture Society for a Research Grant to help raising public awareness of wood as an eco-friendly material and its significant role in world history. Finally, I wish to thank copy editors Pieter Baas and Harvey Green, for their precious advices. 


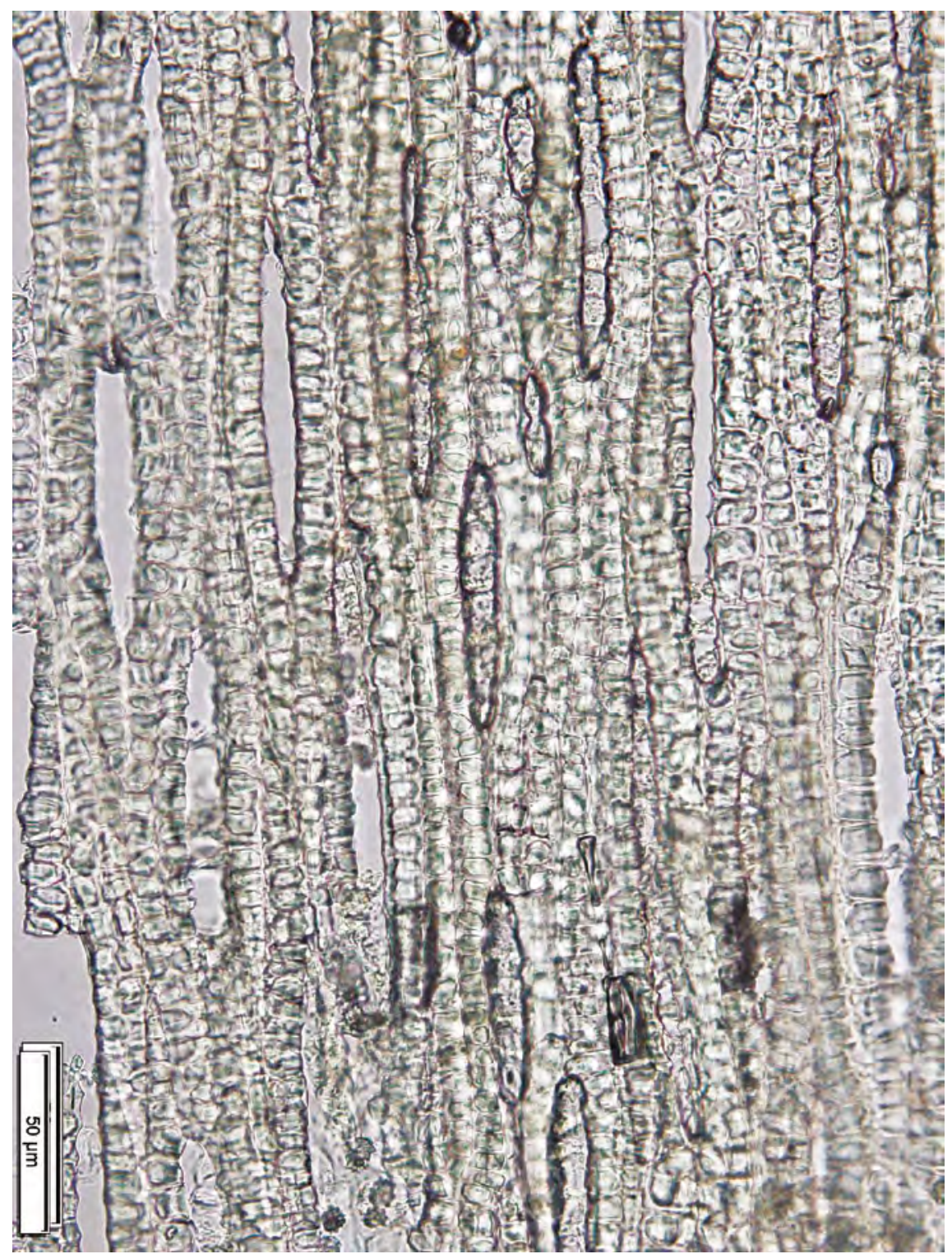

FIGURE 15 Sample No. 76 from Tsa Tsa Puri temple, room 3. Tangential section of poplar bark. The bark had remained attached to the roundwood sample. The rays are only visible as hollow shapes. The bark tissue is mainly composed of very long strands of chambered cristalliferous phloem parenchyma. 


\section{Appendix}

The following lists the results of the microscopic wood identifications performed in the laboratory of Kyoto University's Research Institute for Sustainable Humanosphere (RISH). The microscopic slides are preserved in RISH's Xylarium. Under the location names are three columns with, from left to right, the serial number under which the slides are preserved at RISH's Xylarium, the structural part name, and the timber species name.

Leh Old Town (18 September 2014) - 3505 m asl, sampling with Stanzin Tundup THF

1. Roke Bano House - early 19oos, lower Stalam Road - ground floor. The house belongs to a Muslim family but is rented by TH F staff.

$\begin{array}{lll}\mathrm{OO1} & \text { Main pillar } & \text { Populus sp. } \\ \mathrm{O} 2 & \text { Bracket on main pillar } & \text { Salix sp. } \\ \mathrm{O} 3 & \text { Main beam/purlin (supported by } & \text { Populus sp. } \\ & \text { bracket and main pillar) } & \\ \text { o04 } & \text { Rafter } & \text { Salix sp. } \\ \text { o05 } & \text { Sticks or talu (on rafters) } & \text { Salix } \mathrm{sp}\end{array}$

2. Sofi House - early 19oos, beside the Stagopilog Stupa Gate

Ground floor

$\begin{array}{lll}\text { oo6 } & \text { Rafter } & \text { Populus sp. } \\ \text { oo7 } & \text { Main beam } & \text { Populus } \mathrm{sp} . \\ \text { oo8 } & \text { Stick on rafter (talu) } & \text { Salix sp. } \\ \text { oo9 } & \text { One pillar } & \text { Populus sp. }\end{array}$

Outer porch

010

One pillar

Populus sp.

3. Stagopilog Stupa Gate, next to Sofi House

011

Beam on ceiling of stupa

Salix sp.

4. Lakruk House - early 170os, Upper Stalam Road, near Leh Palace and Chamba

Gonba. On the top floor, the THF rents an office

1st floor (kitchen)

$\begin{array}{lll}012 & \text { Pillar } & \text { Populus sp. } \\ 013 & \text { Bracket } & \text { Populus sp. } \\ 014 & \text { Main beam } & \text { Populus } \mathrm{sp} . \\ 015 & \text { Rafter } & \text { Populus } \mathrm{sp} . \\ 016 & \text { Stick on rafter }(\text { talu }) & \text { Salix } \mathrm{sp} .\end{array}$


(cont.)

5. West Stupa Gate, next to the Central Asian Museum

017

018
Lintel in wall

Two beams on ceiling of the stupa
Salix sp.

a) Populus sp. b) Salix sp.

6. Two holy trees (Sikh trees) next to the Central Asian Museum. Tree(s) brought from India, wood is used for toothpicks
019
Living tree
Populus sp.
020
Dead tree
Populus sp.

Kanji Village - 3850 m asl (25 September 2014), sampling with Yutaka (THF) + Jigmet Namgial (Achi Association India). All samples deteriorated to various degrees $(24+25$ best $)$.

Tsuglag-khang temple (a one-room structure) - 70o years old Inside

$\begin{array}{lll}\text { O21 } & \text { Main central pillar(deteriorated) } & \text { Juniperus } \mathrm{sp} . \\ \mathrm{O} 22 & \text { Lintel } & \text { Juniperus } \mathrm{sp} . \\ \text { 023 } & \text { Beam support (extremely deteriorated) } & \text { Juniperus } \mathrm{sp} . \\ \text { Outside } & & \\ \text { 024 } & \text { Main pillar } & \text { Juniperus } \mathrm{sp} . \\ \mathrm{O} 25 & \text { Roof-supporting beam } & \text { Juniperus } \mathrm{sp} . \\ \text { 026 } & \text { Central bracket } & \text { Juniperus } \mathrm{sp} .\end{array}$

Wanla Village - $3200 \mathrm{~m}$ asl (25 September 2014). Sampling with Yutaka (THF) + Jigmet Namgial (Achi Association India)

Chuchig-zhal Temple (temple of the Eleven-headed Avalokhiteshvara [Chuchigzhal]) - 7 oo years old

Inside

$\begin{array}{lll}\text { O27 } & \text { NW pillar } & \text { Pinus wallichiana (syn. P. excelsa) } \\ \text { 028 } & \text { NE pillar } & \text { Pinus wallichiana } \\ \text { 029 } & \text { SE pillar base } & \text { Conifer ? (extremely det.) } \\ \text { 030 } & \text { SE pillar shaft } & \text { Pinus wallichiana } \\ \text { 031 } & \text { SW pillar base } & \text { Salix sp. }\end{array}$


(cont.)

\begin{tabular}{|c|c|c|}
\hline 032 & SW pillar & Pinus wallichiana \\
\hline O33 & Entrance door frame & Salix sp. \\
\hline \multicolumn{3}{|c|}{ Outside } \\
\hline O34 & NW pillar (right side) & Pinus wallichiana \\
\hline 035 & NE pillar (left side) & Pinus wallichiana \\
\hline 036 & Right pillar's bracket & Salix sp. \\
\hline 037 & Lion bracket & Salix sp. \\
\hline 038 & Left pillar's under bracket & Salix sp. \\
\hline O39 & $\begin{array}{l}\text { Beam on top of bracket } \\
\text { (right side) }\end{array}$ & Salix sp. \\
\hline 040 & Lintel above entrance door & Salix sp. \\
\hline 041 & Mani wheel & Salix sp. \\
\hline 042 & Entrance door sill & Salix sp. \\
\hline
\end{tabular}

Alchi village: Alchi Monastery - 306o m asl (26 September 2014) Sampling with Yutaka (THF) + Jigmet Namgial (Achi Association India)

Lotsawa Lhakhang - 11-12th century

$\begin{array}{lll}043 & \text { Main central pillar } & \text { Populus sp. } \\ 044 & \text { Door lintel } & \text { Populus } \mathrm{sp} . \\ 045 & \text { Main beam } & \text { Populus } \mathrm{sp} . \\ 046 & \text { Lion bracket (prob. Juniperus) } & \text { conifer } \\ 047 & \text { Rafter } & \text { Populus } \mathrm{sp} . \\ 048 & \text { Board between rafters } & \text { Populus } \mathrm{sp} . \\ 049 & \text { Ceiling board } & \text { Populus } \mathrm{sp} . \\ 05^{\circ} & \text { Bracket on top of main pillar } & \text { Populus } \mathrm{sp} . \\ \text { 051 } & \text { Small bracket under big one } & \text { Populus } \mathrm{sp} .\end{array}$

Tsa Tsa Puri (three separate rooms, one two-storied the others one-storied) ca. $15^{\text {th }}$ century

Room 1

$\begin{array}{lll}0_{5} & \text { SE pillar } & \text { Populus sp. } \\ 053 & \text { SW pillar extremely deteriorated } & \text { Populus } \mathrm{sp} . \\ 054 & \text { NW pillar } & \text { Populus } \mathrm{sp} . \\ 055 & \text { NE pillar } & \text { Populus } \mathrm{sp} . \\ 056 & \text { Door lintel } & \text { Populus } \mathrm{sp} .\end{array}$


(cont.)

$\begin{array}{lll}057 & \text { Door frame } & \text { Populus sp. } \\ \text { 058 } & \text { Door blade } & \text { Populus sp. } \\ 059 & \text { Door sill } & \text { Populus sp. }\end{array}$

Room 2

\begin{tabular}{|c|c|c|}
\hline o6o & NW pillar & Populus sp. \\
\hline o61 & NE pillar & Populus sp. \\
\hline $\mathrm{o} 62$ & SE pillar & Populus sp. \\
\hline o63 & SW pillar & Populus sp. \\
\hline o64 & Floorboard & Juniperus sp. \\
\hline 065 & Floorboard frame (nodules) & Juniperus sp. \\
\hline o66 & Door frame & Populus sp. \\
\hline o67 & Door lintel & Populus sp. \\
\hline o68 & Door sill & Populus sp. \\
\hline
\end{tabular}

Room 3 (2nd floor of room 2)

\begin{tabular}{|c|c|c|}
\hline o69 & Rafter & Populus sp. \\
\hline 070 & Main beam & Populus sp. \\
\hline 071 & SW pillar & Populus sp. \\
\hline 072 & SE pillar & Populus sp. \\
\hline 073 & Small bracket & Populus sp. \\
\hline 074 & Big bracket & Populus sp. \\
\hline 075 & Top beam & Populus sp. \\
\hline 076 & Rafter & Populus sp. \\
\hline 077 & Ceiling board & Populus sp. \\
\hline 078 & Lion bracket & Populus sp. \\
\hline O79 & Window frame & Populus sp. \\
\hline o8० & Door lintel & Populus sp. (deteriorated!) \\
\hline o81 & Hinge (scharnier) & Populus sp. \\
\hline 082 & Door blade & Populus sp. (deteriorated!) \\
\hline o83 & Door sill & Populus sp. \\
\hline o84 & Willow (?) paraped (from outside) & Salix sp. \\
\hline
\end{tabular}

Room 4

$\begin{array}{lll}\text { o85 } & \text { SW pillar } & \text { Populus sp. } \\ \text { o86 } & \text { Northern supporting beam } & \text { Populus sp. } \\ \text { o87 } & \text { SE pillar } & \text { Populus sp. }\end{array}$


(cont.)

\begin{tabular}{lll} 
o88 & Small bracket on SE pillar & Populus sp. \\
o89 & Bigger bracket & Populus sp. \\
o9o & Rafter & Populus sp. (deteriorated!) \\
o91 & SW pillar beam & Populus sp. (deteriorated!) \\
o92 & Ceiling board & Populus $\mathrm{sp}$. \\
o93 & Window frame & Populus $\mathrm{sp}$. \\
\hline
\end{tabular}

Chumathang - 4050 m asl, "Old Temple". Sampling with Yutaka and Stanzin Tundup of the THF (4 October 2014)

\begin{tabular}{|c|c|c|}
\hline 094 & South pillar (left from entrance) & Populus sp. \\
\hline Os & Bracket on south pillar & Populus sp. \\
\hline os & North pillar & Populus sp. \\
\hline Os & Bracket on north pillar & Populus sp. \\
\hline 098 & Main beam/purlin on top of rafters & Populus sp. \\
\hline$O S$ & $\begin{array}{l}\text { Board between rafters on top of } \\
\text { og } 8\end{array}$ & Populus sp. \\
\hline 100 & Rafter 1 & Salix sp. \\
\hline 101 & Rafter2 & Salix sp. (semi-ring porous) \\
\hline 2 & Door lintel & Populus sp. \\
\hline 10 & Door frame & Populus sp. \\
\hline 104 & Door sill & Populus sp. \\
\hline 105 & Door hinge & Populus sp. \\
\hline
\end{tabular}

Basement

$\begin{array}{lll}106 & \text { Door hinge of basement } & \text { Populus sp. } \\ 107 & \text { Door frame } & \text { Populus sp. (ray cells roundish) } \\ 108 & \text { Lintel 1 } & \text { Populus } \text { sp. } \\ 109 & \text { Rafter } & \text { Salix } \text { sp. (little resin) } \\ 110 & \text { Lintel } 2 \text { (vessel-ray pits net-like) } & \text { Salix } \text { sp. (resin abundant) }\end{array}$

Presented by Reeyork Guesthouse, Leh (4 October 2014)

111

Branch piece of juniper (needle Juniperus sp.

parts are used as incense for

purification) 


\section{References}

ACHI Association, Switzerland, restoration report. Available online at www.achi association.org (accessed 13 June 2019).

Cartwright C. 2015. The principles, procedures and pitfalls in identifying archaeological and historical wood samples. Annals of Botany 116(1):1-13.

Chan F. 2010. Jullay, Ladakh-i, A. Alexander (ed.). Tibet Heritage Fund (no page numbers).

Corkhill Th. 1979. The Complete Dictionary of Wood. Dorset Press, New York, NY.

Gamble J.S. 1972. A Manual of Indian Timbers: An Account of the Growth, Distribution, and Uses of the Trees and Shrubs of India and Ceylon with Descriptions of their Wood-Structure (Second Reprint). Bishen Singh Mahendra Pal Singh, Dehra Dun.

Mertz M., Gupta S., Hirako Y., de Azevedo P., Sugiyama J. 2014. Wood selection of ancient temples in the Sikkim Himalayas. IAWA Journal 35: 444-462.

Pearson R.S., Brown H.P. 1932. Commercial Timbers of India. Government of IndiaCentral Publication Branch, Calcutta, 2 vols.

Wheeler E.A., Baas P., Gasson P. (eds). 1989. IAWA list of microscopic features for hardwood identification. IAWA Bulletin 10: 219-332.

Wikipedia. 2019. Leh. Available online at https://en.wikipedia.org/wiki/Leh (accessed 8 October 2019). 